\title{
Entrevista
}

\section{OLIMPÍADA DO CAp-UERJ - 40 anos de história e memórias}

Por: Esequiel Rodrigues de Oliveira Lincoln Tavares Silva

Sônia Wanderley

Nesta seção da Revista e-Mosaicos, registramos entrevistas feitas em dois momentos, versando sobre o mesmo tema: a Olimpíada Escolar do CAp-UERJ. Em 2012 ela completou 40 anos de existência e, ao longo do ano de 2013, foram sondados alguns de seus protagonistas, por meio de escolhas e indicações que buscaram retratar momentos deste processo e da prática pedagógica e socializante que nos ajuda a contar a história da instituição. Os dois momentos de entrevistas foram compilados articuladamente, de modo a que, dentro do possível, pudessem manter, de forma não-linear, a contação dessa história com coerência e coesão. Participaram desta prospecção e elaboração os docentes Esequiel Rodrigues, Lincoln Tavares e Sônia Wanderley, como entrevistadores. Os entrevistados foram os professores Aristônio Gonçalves Leite Jr., Celby Santos, Marcelo Miragaya dos Santos, Ivan Mihessen, Denise Mihessen e Raul Ferreira Neto. O suporte das gravações e a base das transcrições foram feitos por bolsistas do NEPE (Caroline Lopes de Souza) e do LEDEN (Maria Êda Amadeu Barino). Há muitas visões sobre a Olimpíada do CAp-UERJ e as retratadas aqui abrem leques para que outras sejam buscadas, estudadas e publicizadas. Uma coisa é certa: o processo e o evento de sua culminância são indiscutíveis marcas da instituição.

Entrevistadores: Antes de qualquer coisa, muito obrigado, por vocês terem vindo. Há algum tempo, vimos nos planejando para conseguir uma entrevista com vocês, da Educação Física, para a revista e-Mosaicos, que é a revista que o CAp criou e conseguiu editar a partir de 2012, sendo uma revista acadêmica, que possui uma seção de entrevistas.

Nessa entrevista inicial, resolvemos, na equipe do NEPE, Núcleo de Extensão, Pesquisa e Editoração, que eu (Lincoln) e Esequiel, responsáveis pela seção de editoria de entrevistas e, juntamente com a professora Sônia Wanderley, com quem compomos esta primeira editoria de entrevista, prestar uma homenagem à equipe de Educação Física, por conta dos 40 anos de Olim- 
píadas. Isso foi unânime na discussão de escolha, ocorrida no ano passado. Parte das perguntas da entrevista foi elaborada pela Sônia, que merece muito esse crédito. Ela conseguiu fazer essa mesma entrevista com o Aristônio, anteriormente. E, ao final, pretendemos associar os dois momentos de entrevista em um grande bate-papo. Esta é a nossa intenção.

Entrevistadores: A intenção, desde o início, é que falem espontaneamente do sentimento a que, nos bastidores, você (Raul) fez referência, por exemplo, sobre seu trabalho com a Denise. Consequentemente, o afeto, a memória afetiva veio à tona. É falar com o coração. É o professor fundador (Celby) falando da fundação, é o professor Miragaya falando da participação como aluno e como docente. O Ivan, que cuidadosamente orientou o processo no último ano do meu (Esequiel) filho Vitor aqui...

Denise: ...da inscrição para chefes de bandeira!

Entrevistadores: Isso! Da inscrição para chefes, pela equipe de Educação Física. É. São lembranças adoráveis. Pretendemos não chorar.

Todos: Risos.

Entrevistadores: Isso mesmo. Então podemos começar?

Todos: Sim.

Entrevistadores: Na verdade, são perguntas que a gente fez um pouco "trazendo nos dedos", mas eu acho que, em determinado momento, vocês estarão conduzindo a entrevista. Então se sintam bastante à vontade para falar o que vocês acham que tem a ver com esse objeto: a Olimpíada. É em cima dela que vamos tentar fazer "as costuras". Tanto a gravação, quanto o texto vão ficar no acervo de memória do CAp e vão ser publicados. Eles estarão disponibilizados na rede também.

Entrevistadores: Há uma finalidade que não vai somente pela linha da homenagem, mas também é formativa. O CAp tem sido estudado. E este é um material que tem que ser estudado. Vários desses materiais têm sido acessados por pesquisadores. E, para muitos pesquisadores na área de Educação, com certeza, a entrevista que vocês estão dando hoje será uma contribuição para a formação de professores, para a formação da Educação Básica, para essa cidadania diferenciada que a gente, com todas as dificuldades do mundo, tenta costurar e ter aqui. E essa coisa de ser professor, de não deixar de gostar..., de voltar, de não ter melindres para voltar à instituição. Falar um pouco sobre isso e sobre as dificuldades, as facilidades, as alegrias, as tristezas. Então nós temos aqui o professor Ivan Mihessen, a professora Denise Mihessen, o profes- 
sor Raul, o professor Celby e o professor Miragaya. Todos eles fazem parte, porque nunca deixaram de fazer parte, da equipe de Educação Física, do Departamento de Educação Física e Artística, daqui da instituição, do antigo Colégio de Aplicação. E hoje eles estão aqui para falar sobre algo que é muito importante para esta Unidade. Como pode também testemunhar o meu colega de trabalho Esequiel, professor de Desenho, eles vão falar sobre Olimpíada do CAp-UERJ, pois é assim que permanece a sigla da instituição, a sigla que vai na Olimpíada, há 40 anos, um processo que se dá e que neste ano de 2013 nós vamos viver o $41^{\circ}$ aniversário. Esta entrevista vai tentar obter um pouco da experiência que cada um deles produziu nesses 40 anos de vida de Olimpíada. Eu vou começar aqui com Celby, porque toda vez que tem Olimpíada ele lá está, comparece. Então ele não deixou de viver esses 40 anos de Olimpíada. Importa destacar que é o CAp, é o Colégio de Aplicação, mas nós estamos falando de formação de professores. O então Colégio de Aplicação, por conta das experiências, propostas, práticas pedagógicas e de pesquisa, se tornou o Instituto de Aplicação, com inserção no nível superior, mantendo seu vínculo estreito com a prática da Educação básica, razão pela qual a sigla CAp-UERJ, que consta na Olimpíada, foi preservada.

Entrevistadores: Que relações vocês efetivamente mantêm ou mantiveram com o CAp-UERJ? Celby: Vou começar. Bom, primeiro a relação se mantém. CAp-UERJ e Instituto, a relação faz com que se permita a obrigatoriedade do melhor ensino e da melhor prática educativa. $E$ assim surgiu a Olimpíada. Foi nesses parâmetros que ela foi pensada. E foi pensada dentro de uma Feira de Ciência. O professor Miragaya dirigiu a Feira de Ciência. E foi dentro dela que surgiu a discussão da Educação Física. A ciência "Educação Física" se instalando numa escola onde já existiam as práticas muito bem dirigidas, mas pensando um conjunto diferenciado. Esse foi o ponto inicial dessa história de Olimpíada.

Entrevistadores: O diretor da Unidade era então o professor Miragaya, era isso?

Celby: O professor Miragaya era o professor da Feira de Ciência.

Miragaya: Em que época foi isso?

Celby: 1975.

Miragaya: 1975, o professor Miragaya, para não confundir comigo, que também sou Miragaya, era meu tio, também conhecido como o professor Miragaya. Meu tio, Fernando Miragaya, que em 1975 era vice-diretor do professor Fernando Sgarbi, quando este último foi pra Sub-reitoria da UERJ. E, em 1975, meu tio assumiu a função de Diretor do CAp-UERJ. E aí, no ano seguinte, 
acho que houve uma nova eleição, uma nova escolha. Eu não me lembro do processo.

Entrevistadores: Professor Celby, o senhor já estava aqui desde quando?

Celby: Eu estava no Instituto de Educação Física da UERJ, onde o professor Ivair Machado ordenou que houvesse um estudo e uma mudança sistêmica na atividade de Educação Física, buscando um entrelaçamento cada vez maior com todas as outras disciplinas. Nós, os professores, comporíamos um grupo novo. Eu, Jorginho, Ernani e o saudoso professor Mascarello, viemos para cá, para montar uma estrutura. Era exatamente algo como deveria ser o desenvolvimento da atividade de Educação Física no Colégio de Aplicação. E aí surgiu a conversa com os professores Paulo Sérgio, Moisés, Farias, com o professor Miragaya, a possibilidade da realização de um evento chamado Olimpíada, mesmo sabendo, na época, que o comitê olímpico brasileiro proibia, por determinação, a realização de qualquer evento esportivo que tivesse o nome "Olimpíada". Graças a Deus, o Colégio de Aplicação foi autorizado a ter Olimpíada, que é uma situação importante a ser observada.

Ivan Mihessen: Foi o professor Celby que me convidou para trabalhar no CAp.

Entrevistadores: Fala um pouquinho dessa história para a gente...

Celby: Eu posso ajudar, eu posso ajudar. O professor Édson de Almeida Ramos, que era o vicediretor do Instituto de Educação Física e o professor Ivair Machado, Diretor Geral do Instituto de Educação Física...

Entrevistadores: É o Edinho?

Todos : É!

Celby: ...que hoje é também Diretor. Ambos pensaram nessa estrutura. Porque o professor Ivair Machado era professor da faculdade, da Federal de Educação Física e da Escola Nacional de Educação Física. Ambos lançaram esse desafio, e a nossa turma manteve o desafio nos três anos posteriores. Na saída dos melhores alunos, foram formados professores de Educação Física, funcionários de Educação Física, durante a estrutura da Universidade Federal e da UERJ. Nós fomos alguns desses que vieram para cá. Edinho e Ivair dirigiam o Instituto de Educação Física, que atendia primeiramente aos universitários e que se tornou o IEFD e então ele, o Ivan, veio para cá. Foi o primeiro professor que diretamente se fixou.

Entrevistadores: Ah, é?

Ivan: Eles, Edinho e Celby, é que deram o aval para que quatro pessoas viessem para cá. Viemos eu, Maria Elisa, Rosane e Paulo Fonseca. 
Ivan: É. Ele sabe de tudo. (apontando pra o professor Celby)

Celby: Aqui estavam o professor Paulo Fonseca, a professora Maria José, o professor Carlos Alberto e o professor Eduardo Viana. Esses quatro eram professores cedidos ao Colégio de Aplicação. O professor Ivair Machado, ao montar o Instituto, que foi formado por um grupo de professores da universidade, olhou para o Colégio de Aplicação, com uma obrigação que aproximava o Colégio de Aplicação da formação superior, na qual os futuros professores viriam para cá. Então eu vim como o primeiro, desenvolvendo trabalho com respeitabilidade, juntando com mais professores na área de Educação Física. Isso não quer dizer que havia uma nova proposta. Era apenas uma proposta pedagógica diferenciada. Mas uma proposta pedagógica com necessidade de aproximação da família, do alunado e do corpo docente, tornando-se, então, um campo de pesquisa muito mais aprofundado. Essa foi a nova proposta. Por isso, o surgimento da questão na Feira de Ciência. Uma magnífica Feira de Ciência que já existia, incentivada pelo professor de Matemática, o professor Paulo Sergio, pelo professor Moisés, pelo professor Miragaya, ele era efetivamente o homem da ciência. Que era de Biologia.

Entrevistadores: Estamos aí em que época? Em que ano?

Celby: $1975 \ldots$ por volta de agosto de 75 .

Entrevistadores: Como é que esse projeto, na época, se relacionava com a proposta pedagógica da equipe de Educação Física da escola? Como era essa relação?

Aristônio: A Olimpíada sempre foi valorizada, tá? Todo trabalho relacionado a ela é feito durante o ano. Desenvolvimento do corpo, desenvolvimento físico, é... Psicológico, né...? O trinômio biopsicossocial. Então é uma culminância em que os alunos eram motivados também por serem divididos em bandeiras, como se fossem países, e dentro desses países havia os dirigentes, que são os chefes de bandeira, que se organizavam em equipes. Então era uma integração que até hoje a escola toda vive. Então você vê um aluno do $3^{\circ}$ ano do Ensino Médio que conhece 0 aluno do $1^{\circ}$ ano do Ensino Fundamental. Eles se falam, conversam.

Entrevistadores: Perfeito. Você entrou aqui quando, Ivan? Lembra?

Ivan: Em 73. Um ano como estagiário... em 1973.

Entrevistadores: Denise?

Denise: Eu entrei aqui em 1983.

Entrevistadores: Raul?

Raul: É... 1976... 1980! 80. 
Entrevistadores: Mira, quando você saiu daqui? Se é que você saiu. (risos)

Todos: Risos.

Miragaya: Eu me considero ainda presente. Entrei como aluno em 1978, na terceira série, que hoje seria o quarto ano do Ensino Fundamental. Ainda na sede da Rua Haddock Lobo, que a gente chamava carinhosamente de "Capinho". Minha professora de Educação Física era a professora Maria Luiza que saiu da escola quando eu passei para a $5^{a}$ série. Em 1980, havia o ritual de passagem do "Capinho" para a o CAp, na Barão de Itapagipe. Eu entrei no que seria hoje o $6^{\circ}$ ano ou a $5^{a}$ série da época, em 1980. Em 1985, eu fui chefe da bandeira vermelha, participando mais ativamente da Olimpíada, e saí do colégio, eu já tinha te falado, em 1987. Mas foi em 86, meu último ano. Entrei na Universidade, na UERJ. E aí tive as portas abertas aqui sempre. Os professores, mesmo no meu primeiro e segundo ano, me permitiam vir da UERJ, e eu vinha para cá e fazia estágio, mesmo que na forma de estágio informal. E depois fiz, participei como estagiário em 1991, nos dois semestres e, em 1993, eu aceitei o primeiro convite para participar de um processo seletivo. Não fui contratado, acabei não entrando, até que entrei em 1994. Aí fiquei nesse $1^{\circ}$ período durante quatro anos, e depois tive que sair e seguir as limitações de contratação anual que a UERJ passou a adotar, alternando anos dentro e outros na espera.

Celby: Um detalhe, um detalhe importante é a participação da Associação de Pais. Eles foram primordiais para o desenvolvimento da Olimpíada. Eles se envolveram de tal maneira, os pais, que na I Olimpíada, diferente das outras, teve um sorteio com letras e nomes. Uma mesma família tinha pessoas em uma bandeira e pessoas em outra bandeira. Daí, você torcia para a bandeira de que você gostava, com filho ou não. Você tinha que ajudar a outra bandeira e então foi uma grande ligação, na Escola de Educação Física do Exército, que deu um grande apoio, para o Instituto. Lembrando agora da professora Maria Elisa, nem se fala, o coração acelera, sempre sacode com o CAp-UERJ.

Entrevistadores: Vocês têm é história para contar sobre os anos em que permaneceram no Colégio de Aplicação. Como vocês veem a relação do evento com o restante do CAp?

Denise: Diferentes momentos e diferentes espaços também, né? Porque a gente tinha esses espaços bem diferentes. Quando eu entrei aqui em 1983 e antes, em 1981, para substituir a professora Eliza que se foi e eu fiquei. E eu fiquei impressionada porque eu vinha de colégios públicos, sempre estudei em colégios públicos, e tinha muito interesse pelo esporte. Eu me a- 
chava muito feliz por estar participando daquele esquema da nossa escola. Quando eu cheguei aqui, eu fiquei impressionada com a ligação e o movimento que existiam. Não era só a equipe de Educação Física envolvida. Eram os pais, eram os pais através da Associação, eram pais muito legais que se interessavam, os inspetores, toda a instituição. Vivemos um movimento de envolvimento dos professores de outras disciplinas. Então a gente teve fases assim, épocas em que o professor acompanhava diariamente as nossas aulas e daí levava o material como subsídio disponível para trabalhar em sala de aula. A gente tem relatos lindos, né? Existiu também o envolvimento com o grupo de Língua Portuguesa. Teve uma época em que havia entrevistadores. Alguns se interessavam muito pela atividade esportiva, mas aqueles que não se sentiam à vontade com a participação esportiva não ficavam de fora, só olhando. Eles tinham uma participação como entrevistadores, como fotógrafos, né? Em cada época houve um envolvimento bem legal com todas as disciplinas. Em relação ao nosso trabalho, a gente sempre estava muito próximo do primeiro segmento. Eu e Raul sempre estávamos muito próximos ao professor de turma. Aí a gente fazia os trabalhos mesmo assim. Por exemplo: um aluno vai fazer salto em distância na aula, então vamos anotar, vamos fazer sua tomada de tempo, levar para a sala de aula, para ver a parte lógica.

Entrevistadores: Como assim? Explica isso?

Denise: Tinha assim, a composição da prova, e várias avaliações trabalhavam muito em cima de nossas questões esportivas, né? E isso encantava as crianças. Eu tenho um exemplo, que é muito marcante, de um aluno que não se sentia nem um pouco à vontade em fazer aula, mas era muito atento. Então, um belo dia, nós estávamos sem a trena para medir o salto em distância, e eu fiquei assim: "Nossa! O que nós vamos fazer? A minha fita métrica não está aqui, não tem como eu fazer!". Aí ele vem, o Pedro, e me diz assim: "Vamos usar uma corda e depois a gente transforma em números". E nós usamos a corda e fomos vendo. Quem saltava um pouco mais que a corda, ele dobrava a corda em tantas vezes, até pegar aquele pedacinho. Aí ele falava: "Ele saltou uma corda e um oitavo da corda". E ele estava estudando, na época, fração, né? Então ele levou esse material para a sala de aula e foi um encanto, né? Eu pensei assim: "Isso aí..., só profissional mesmo". (risos)

Celby: Essa base da proposta é a grande diferença de um Instituto de Educação. O evento sempre tem o diretor presente, uma obrigação. Uma obrigação estar presente, pois mudanças naturalmente têm que existir, mas isso não significa que se perde a essência. Então é o grande jaca- 


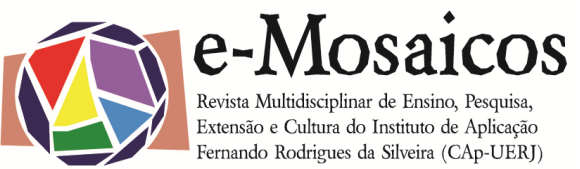

randá que deu certo.

Entrevistadores: Miragaya, e a sua experiência? Tem algum diferencial?

Miragaya: Como aluno, total em vida de escola, principalmente, como o professor Celby falou, aqueles colegas que não tinham tanta aptidão ou gosto pelo esporte não deixavam de participar de alguma forma.

Ivan: Eu gostava, pois havia também o xadrez.

Miragaya: E aí realmente, uma das coisas que me chamavam atenção era isso. A gente não tinha somente as modalidades esportivas mais conhecidas, como as de quadra, né? Voleibol, basquete, o hoje chamado futsal e o handebol. A gente tinha o xadrez, o tênis de mesa, o totó, o futebol de botão.

Ivan: É. Você gostou e até ganhou!

Miragaya: Havia um envolvimento que se o cara não gostava de jogar futebol ou vôlei, ele ia jogar um "totozinho" ali, e ficava "amarradão", ou então jogava o tênis de mesa e ficava amarradão. E também participava do desfile. Não existia chamada, como a gente teve que fazer há alguns anos, aí virou burocrático. Na tradição, a gente não fazia chamada para o desfile. Não dava presença no desfile. A gente ia para o desfile numa alegria que era um absurdo. E os outros professores também compareciam. Eu até comentei um pouco antes. Eu me lembro que, no início, as aberturas se davam às quintas-feiras à tarde. É, até hoje, o horário de reunião de professores da escola. Por conta disso, era mais um motivo para que os professores estivessem presentes. Alguns acompanhavam os alunos, até brincavam com a gente até o momento em que a gente terminava a Olimpíada. Eu acho que a importância de todo esse projeto, de todo esse envolvimento, é mostrada até hoje, claramente, no calendário, onde existe isso lá marcado, quando a escola altera as atividades, por uma semana. Se você contar direitinho, é pouco mais de uma semana. Voltam-se as atividades da escola para se trabalhar apenas Olimpíada, Olimpíada e Olimpíada. Então eu acho que isso tudo mostra o envolvimento da escola. Mas eu não posso me furtar de falar uma coisa aqui. Quando eu fui aluno das séries iniciais, $3^{a}$ e $4^{a}$ séries, a gente tinha apenas a participação no atletismo. Obviamente os alunos, é..., vamos dizer assim (risos) "um pouco mais fortes" como eu (risos), a gente não tinha a oportunidade de participar. E a partir do momento que Raul entrou e depois com Denise, a participação do primeiro segmento passou a ser tão grande quanto a do restante da escola. Um ano depois a gente passou a jogar futsal, handebol feminino e masculino, câmbio. E aí, depois, as outras ativida- 
des individuais, como totó. A cada ano Raul sempre brigava mais pelas ações. E com razão, né? E eu não podia deixar de falar isso. E depois Denise esteve ali, na assessoria dessa briga. Raul: Era uma briga pacífica. (rindo)

Entrevistadores: Retomando, além do projeto da disciplina, há a questão de integração dos alunos.

Aristônio: E uma coisa interessante, os professores de outras disciplinas se integraram com esse trabalho. Eu me lembro do professor Willson. Ele vinha, desfilava com a bandeira... A... A... Leda Beatriz desfilava com a bandeira... Paulo César Sgarbi, ele fazia parte da nossa equipe de organização. A Leila Medeiros e a Associação de Pais também, né? A Dona Zulmira, que faleceu no ano passado. Então é uma integração geral dentro do colégio, com os funcionários. Você vê esse ano, o funcionário que já saiu daqui do CAp e que hoje está na faculdade, dentro da prefeitura da universidade, o André, vai lá e participa. Como os ex-alunos, ex-professores que voltam pra cá. O caso do professor Miragaya, que foi aluno, né? Foi aluno, foi estagiário e professor. Mesmo afastado agora, volta para ajudar também. E isso é muito bacana, essa integração total que existe. $\mathrm{E}$ as expectativas dos alunos? Todo início de ano é essa: como é a inscrição para chefe de bandeira? Quando é que começa? Porque é um processo pedagógico. É como se fosse uma eleição... para o Senado, para a Câmara, para Vereador. Há as campanhas, as regras para quem pode, né? A gente tem de tudo hoje em relação ao que acontece. Há o ficha limpa, né? Aqui nós temos o ficha limpa também.

Ivan: Ele também participou do judô.

Entrevistadores: Como foi essa parte que Miragaya traz? Como foi isso Raul?

Raul: Não tem como não falar do CAp-UERJ, sem traçar uma linha de tempo. Parece que está faltando algo aqui. Como começou esse processo das divisões por bandeira? Que foi e é um diferencial do CAp. Por que foi aí que começou? Bem, o primeiro segmento começou em 1976, né? Só havia turmas de $3^{\circ}$ e $4^{\circ}$ ano, antigas séries. Em 1977, eu fui aluno mestre, fui aluno do professor Celby, que já havia colocado, nas aulas dele, como era o processo. E eu vim participar da Olimpíada como aluno-mestre. O CAp sempre foi um espaço que contribuiu para a formação dos professores de Educação Física, formados pelo instituto. Presenciei a abertura sensacional e depois entre 1979 e 1980, quando eu cheguei no CAp, os segmentos eram bem separados. Falando de $5^{\mathrm{a}}$ a $8^{\mathrm{a}}$. Havia uma separação tremenda. Tudo vivia em função dos alunos lá do Turano (hoje Ensino Médio). Quando eu cheguei aqui, a equipe de Educação Física, que na época 
era formada pelo professor Ivan, saudoso Mascarello, Maria Eliza, Rosanne, Lia, o Aristônio, que já trabalhava aqui, e o professor Paulo Fonseca. Quando eu cheguei aqui, só participavam da Olimpíada o $3^{\circ}$ e $4^{\circ}$ anos, que jogavam, que participavam do atletismo, até porque a professora, que infelizmente deixou o CAp, era técnica de atletismo. E ela trabalhava o atletismo, mas não havia tanto espaço para desenvolver esse trabalho. Trabalho sensacional. Fazendo parênteses: me lembro de uma menina, Marcinha, que foi fazer um rolo para a frente, era bem "fortinha", com a técnica superou e conseguiu fazer um movimento, que dizíamos que tinha varinha e tal e a turma toda aplaudiu. Quando ela conseguiu fazer, ficou claro que ali havia uma técnica, uma profissional sensacional por trás. Aí eu levei isso para a equipe, e todos aceitaram em expandir e naquele ano estava começando o $1^{\circ}$ ano da $1^{\text {a }}$ série do Ensino Fundamental, certo? A turma que a Leila adora, mas não só a Leila, nós adoramos. Nesse momento me veio a ideia de fazer uma estafeta. Mas, o que é uma estafeta? E se você não sabe, vai saber agora o que é a estafeta. O que é? É uma corrida com obstáculo. Uma corrida com obstáculo? E foi um "tal, tal e tal" e, depois, Denise vai contar, criou-se uma história da estafeta. Essas crianças tiravam os tempos, durante as aulas. Era uma corrida de 5 obstáculos, prova de revezamento. Você ia, fazia o outro na frente, um espaço, uma corda, pulava, nós utilizamos a corrida, saltos. Isso tudo começou numa quinta-feira na Haddock Lobo. E para a minha frustração não apareceu ninguém. Assim, um chefe de bandeira, todos os colegas ficavam com outras coisas, eu fiquei sozinho, porém meu amigo, isso me emociona demais. Aquela quadra da prova tava superlotada, os pais participavam. Faço aqui outro parênteses, no CAp, além de todos os diferenciais, é muito significante o processo família-escola. Aqui há a participação da família. É o processo escola-família. Nessa história a família participa. E os pais foram, foram tanto que tivemos que segurar as cordas para segurar os pais das crianças. E graças a Deus (rindo) a Olimpíada fez sucesso. No outro ano (rindo), ah (risos) essa estafeta não fez parte do convite. Fiquei muito triste. Mas eu tinha que lutar, sabe? Mas sozinho, sozinho.

Entrevistadores: Mas, nessa época já havia bandeira?

Raul: Já havia bandeiras, já havia divisões. As quatro bandeiras eram todas divididas. O Celby já vai explicar as origens das bandeiras. Já havia as bandeiras e, uma vez, eu saí na véspera e a professora Celina Bittencourt, de Artes, me ajudou a vender as camisetas da Olimpíada. A equipe me deixou vender as camisetas sozinho. Eu é que vendia. Saí às 19 horas de lá de cima, do $3^{\circ}$ andar. A Celina me ajudando a vender as camisetas para os pais. Mas foi muito sucesso. Só 
sei que no outro ano, a estafeta passou a fazer parte da Olimpíada. Aí o professor Mascarello teve a grande sacada. Essa estafeta não pode ser assim. Tem que acontecer no encerramento. Como não pode? (falando sussurrando) Aí, vem Denise, a Denise também chegou ao CAp, assim como eu, para trabalhar com um novo primeiro segmento. A gente trabalhava só com o primeiro segmento. Aí tínhamos que nos dedicar, fazíamos uma apresentação para a abertura, fazíamos uma apresentação para o encerramento, eu não sei como. Mas Deus é grande e dava tempo! Montava pra lá, corria pra cá, papai e mamãe batiam foto e essa estafeta existe desde 1980.

Entrevistadores: Você está falando das modalidades?

Miragaya: Eu também. Isto está de acordo com o que eu falei com a participação das séries iniciais, do primeiro segmento. Tinha uma participação muito curta só com o atletismo. Que era a $3^{a}$ e $4^{a}$ série na época, $4^{\circ}$ e $5^{\circ}$ ano hoje. Eles participavam só do atletismo. É a partir da entrada do Raul, ali no atletismo, que conseguiram participar da estafeta, e além da parte do 40 e $5^{\circ}$ ano, do Ensino Fundamental, todos os outros anos também: $3^{\circ}, 2^{\circ}$ e $1^{\circ}$ ano.

Entrevistadores: Quais os critérios para participação na Olimpíada?

Aristônio: Temos regras para ser candidato. Os pais têm que autorizar, ele tem que estar dentro dos critérios, não pode ser um aluno repetente, ele não pode ter uma ficha de indisciplina. $\mathrm{A}$ participação dele nas aulas de Educação Física, também. Então tudo isso é levado em consideração. Não pode participar, porque está mal com nota em outra disciplina, a gente faz uma "peneira".

Entrevistadores: E mesmo assim os alunos gostam de participar...

Aristônio: Sim. Entram com recurso. Aqueles que são desclassificados entram com recurso. Querem porque querem participar.

Raul: Esclarecimento: em 1980 começou a estafeta. Nós passamos a ter o $1^{0}$ segmento com estafeta, totó, câmbio, handebol, futsal e todos os alunos participavam. Não ficava um aluno de fora. Todos participavam desse processo. Não havia separações. Fazíamos, no papel, as instruções e anotações e as professoras do primeiro segmento faziam a parte de sala de aula.

Entrevistadores: Verdade. E a participação dos alunos? Fala um pouquinho mais...

Aristônio: Uma das preocupações nossas, da equipe, na hora de organizar a Olimpíada, é ter uma maior participação dos alunos. Teve uma época aí, não sei se foi há uns dez anos atrás, na qual caiu bastante a participação dos alunos e, não lembro porque, houve essa queda. Mas hoje 
em dia está aumentando, cada vez mais. Nós temos uma participação de quase mais de $90 \%$ de alunos. Às vezes não tem vagas, a gente cada vez mais cria categorias. Mais futsal A, futsal B, futsal $C$, para poder dar conta das pessoas que querem participar.

Aristônio: E olha que os pais participam, hein! (risos) E..., e os pais..., a guerra entre os pais é tremenda! A gente às vezes tem que frear isso... (risos).

Entrevistadores: Os pais participam?

Aristônio: Poxa, pais participam na torcida!

Entrevistadores: Ah... Eles não podem jogar?

Aristônio: Não... Não... A participação dos pais é dentro bandeiras, das torcidas, com os filhos, com a equipe... Torcendo e reclamando da arbitragem... Reclamando do jogo...

Entrevistadores: Quais são as faixas e categorias? Quais são as atividades?

Aristônio: Antigamente as categorias eram feitas por série, né? Uma categoria era o primeiro segmento; a outra categoria era a $3^{a}$ categoria, que eram os alunos de, na época eram de $5^{a}$ e $6^{\mathrm{a}}$ séries; a $2^{\mathrm{a}}$ categoria era $7^{\mathrm{a}}$ e $8^{\mathrm{a}}$ séries. E a $1^{\mathrm{a}}$ categoria era alunos do Ensino Médio. Hoje e já há alguns anos - a gente já faz por idade, independente da série em que ele está. Porque às vezes tem um garoto que repetiu alguns anos. E já tem 17 anos, na $6^{a}$ série. Ele não vai jogar junto com o aluno de 11 e 12 anos, então a gente faz por data/ano de nascimento.

Entrevistadores: E quais são as atividades, quais são os tipos de modalidades?

Aristônio: $O$ aluno pode participar de uma modalidade individual e duas modalidades coletivas. As individuais são: atletismo, xadrez, tênis de mesa. Estou falando deste ano, porque já tivemos natação. Nós já tivemos futebol de botão, já tivemos... Ah, agora não estou lembrado de tudo. Mas são as modalidades individuais. E há as coletivas que são: futsal, basquete, voleibol, handebol. As estafetas, os alunos do primeiro segmento fazem... Eu devo estar esquecendo alguma coisa. Ah, futebol society.

Entrevistadores: Com o que isso, efetivamente, contribuiu para essas crianças, na visão de vocês?

Raul: Olha rapaz, eu acho que a contribuição foi imensa. O amor. A gente tinha um objetivo que, era o de levar prazer a essa criança por inteiro no que ela tinha; sabia. A partir do momento que sabia (a criança) todos os tempos, era uma forma de conhecer os limites. E naquele momento, a criança sabia que era capaz de fazer de um modo, a outra de outro modo e tinham 
como reconhecer. "Mas eu sou capaz de fazer também". E fazia! O Thomás com o $3^{\circ}$ ano, que não tinha os membros (aponta para os braços) quando entrou aqui, nós tínhamos uma estafeta que tinha que carregar um boneco, feito na aula de teatro. Todo mundo sabia o que ia acontecer. Thomás foi, correu, botou o boneco aqui debaixo do queixo e o ginásio da UERJ todo aplaudiu. Essa criança sempre nos surpreendeu. Só para encerrar, eu acho que a grande contribuição é o prazer que a gente tem de ver que a maioria dos candidatos a chefes de bandeira foram alunos do primeiro segmento, não é Denise? E nós tínhamos certeza, se a Olimpíada fizesse sucesso, essa criança iria.

Miragaya: Está aí outra ressalva, já que ele falou disso. A gente sempre teve aqui, eu digo isso como professor, nitidamente, a gente via o aluno de $5^{\mathrm{a}}$ série, $6^{\circ}$ ano agora, que tinha sido do CAp desde os anos iniciais. A diferença dos que não tinham tido Educação Física nos anos iniciais, a diferença de coordenação motora, de agilidade, de noção de tempo e espaço, era absurda.

Entrevistadores: Fala um pouquinho - como sendo aluno do CAp, depois licenciando, quando fez estágio aqui, depois sendo professor, como professor em várias etapas, chegando a ser depois diretor - das experiências, de algumas memórias que você tenha e que você acha interessantes. Fala sobre essas diversas fases que você viveu com a Olimpíada e da sua participação na Olimpíada.

Aristônio: Minha participação na Olimpíada, na época de aluno, eu fui do grêmio, fui diretor de esportes do grêmio, numa época politicamente, no Brasil, muito conturbada, complicada mesmo. O presidente do grêmio era Chico Alencar. Então as pessoas daquela época lembram o que acontecia. Tanto é que o Chico saiu da escola. Foi "convidado" a sair.

Entrevistadores: "A se retirar"?

Aristônio: Aí, eu não sei porque, deixaram que eu continuasse e eu fiquei. Eu lembro dessa fase, dessa época quando eu organizava. Nós não tínhamos Olimpíadas. Só aulas de Educação Física. Eu tive um professor no meu $1^{\circ}$ ano do colégio, professor Eduardo Viana, falecido já, que foi meu professor lá universidade e foi presidente da Federação de Futebol do Rio de Janeiro, durante anos. Era uma pessoa sempre contestada, mas ele estava sempre ali, junto. Na comunidade da Federação. Os clubes todos o contestavam, "que ele era isso, que ele era aquilo", mas era uma pessoa muito inteligente. Eu acho que foi uma das pessoas mais inteligentes que eu conheci, dentro da minha vida acadêmica. Ele era um professor na minha fase de aluno da Uni- 
versidade. Depois, como professor, eu fui o primeiro chefe do Departamento de Educação Física e Artística, na época em que o Colégio foi departamentalizado. Fiquei em dois mandatos, como chefe de departamento. Eu participei das mudanças todas do colégio. O colégio começou na rua do Bispo e eu já estava lá, passando para a rua Haddock Lobo. Tudo isso eu acompanhei, quando passamos para a rua Barão de Itapagipe. Participação na Feira de Ciência... Eu acho isso uma tristeza, que eu tenho até hoje. Inclusive eu, como diretor, não consegui fazer a Feira de Ciência e era um desejo nosso, meu e do professor Julianelli. A gente não conseguiu e até hoje nós também não temos a Feira de Ciência, que era uma coisa tradicional. Os melhores trabalhos participavam da Feira de Ciência do Estado e a gente não participa mais.

Ivan: Quantas vezes, há um professor agora, que foi aluno nosso do CAp, que volta aqui. Eram alunos meus antes e são professores agora.

Entrevistadores: Essa é uma pergunta que a gente queria fazer pra vocês. O que esse projeto teve, de alguma forma, de influência na decisão profissional de vocês, e na de quem veio depois, que encaixa nisso que o Ivan falou. Será que isso teve alguma influência na sua decisão profissional?

Miragaya: Com certeza, com certeza. Eu me lembro nitidamente do meu primeiro ano de Ensino Médio, que na época era segundo grau. Eu me lembro de que existia uma dúvida minha, se eu tentaria fazer Educação Física, ou não, e no meu $2^{\circ}$ ano, quando eu me tornei chefe de bandeira, essa dúvida começou a se dissipar. Eu já tinha certeza que era aquilo que eu ia fazer. A outra carreira deve ter perdido um grande, sei lá.

Celby: Deve ter perdido um bom profissional, um cara forte.

Todos: Risos de todos.

Miragaya: Um grande contador de histórias

Todos: Risos de todos.

Entrevistadores: Mas, e sobre a memória das Olimpíadas, você como estagiário, como é que você via, essencialmente, o evento como licenciando?

Aristônio: É, eu como estagiário, eu fui monitor. Quando eu fiz estágio, eu era monitor de turno. Já tinha turno. Eu então estagiei na minha turma. Na época que perderam o livro dos monitores, naquela época foi perdido, num incêndio que teve na Barão Itapagipe. Se não, eu teria direito de até mudar de categoria na Universidade, poderia contar meu tempo desde a época de monitoria. E esse livro foi perdido. 
Aristônio: Eu entrei em 1979. Eu me formei, eu colei grau em julho e em $1^{\circ}$ de agosto eu estava contratado na UERJ.

Entrevistadores: Então você lembra dessa diferença, né?! Naquela época você já assumia sala de aula como...

Aristônio: Monitor.

Entrevistadores: E depois como professor. Como você agia como professor, organizando Olimpíadas, alguma coisa, a relação que tinha, com você, lembrava e sentia?

Aristônio: Porque na minha época de monitor - tem até uma foto, na qual estamos na concha acústica da UERJ, no encerramento da Olimpíada - eu estou com o uniforme da faculdade e eu fazia parte da organização da Olimpíada.

Entrevistadores: E depois, como professor, você continuou?

Aristônio: Continuei fazendo a mesma coisa. Aí depois fui coordenador de disciplina. Ah... eu passei por todas as fases.

Entrevistadores: No desempenho de vocês, como profissionais, isso de alguma forma também mexeu dentro de vocês?

Denise: Ah, isso engrandece muito, né?

Raul: Muito mesmo!

Denise: Porque a gente viu que, com esse trabalho, mesmo que o aluno não tivesse tanta habilidade física, tinha aquele envolvimento, o compromisso. A gente teve líderes, como chefes de bandeira, que não eram tão evidentes no esporte. Mas eles assumiam essa atuação na formação da bandeira como superimportante, na organização. E que envolve todo mundo. E quando eles iam ali, já saíam definindo o que e qual era a intenção de aproveitar aquela liderança, ir em frente e colaborar. E também, muitos saíram optando pela Educação Física. Para a gente é um orgulho. A maioria foi...

Miragaya: E muitos falaram que não iriam fazer porque os pais não deixavam.

Entrevistadores: Bom, a participação do projeto da Olimpíada e mesmo a atividade da Educação Física aqui no colégio em que você foi aluno, teve alguma influência na sua opção profissional? Aristônio: É. Eu fui atleta. Então, antes de eu entrar no CAp, eu já jogava, participava de campeonatos.

Entrevistadores: E jogava o que, basquete?

Aristônio: Joguei basquete. Eu jogava basquete, e mais, estimulo, porque é muito difícil. Hoje 
você ainda encontra, mas naquela época, de início, a estrutura de Educação Física do colégio, não existia. Só nos colégios militares. Éramos a única escola, que eu me lembre, que cumpria as deliberações do MEC.

Entrevistadores: De Educação Física?

Aristônio: Sim, de Educação Física. Várias outras escolas "empurravam com a barriga". Então, quando a gente chega, alguns dos estagiários hoje chegam aqui e, com espanto dizem: Nunca tive aula de Educação Física como vocês ministram. Até hoje tem escola que diz que tem aula de Educação Física. Mas não há uma fiscalização, não há nada.

Entrevistadores: E como é que você vê essa questão das aulas de Educação Física nos colégios, porque às vezes os garotos acabam por jogar qualquer coisa. Isso é Educação Física?

Denise: Havia também disso, porque ocorreram épocas em que se dizia: ter diploma do Colégio de Aplicação para dar aula de Educação Física? Vai se professor? Exista uma coisa assim!

Raul: Isso é verdade.

Miragaya: Existia um ditado, eu não sei dizer bem, numa época na UERJ, que dizia que quem não sabia ensinava e quem não sabia nada ensinava Educação Física.

Aristônio: Não. Aqui a nossa finalidade de Educação Física é a formação do individuo. A gente utiliza as modalidades com um meio e não como finalidade. Aqui o aluno se sente identificado com aquela modalidade e caso queira continuar aprendendo mais alguma coisa, a gente passa, trabalha. A gente usa essa modalidade como uma base para poder fazer o desenvolvimento pelo qual o aluno optou. Trabalhar a coordenação motora, noção de tempo e espaço, essas coisas, sabe? E para o aluno que se identifica tem as escolinhas, atualmente, a dispor. Nós tivemos um time feminino aqui do Colégio e o time todo do colégio era time de um clube que foi campão estudantil, foi campeão brasileiro, foi campeão estadual (risos)... E era um time do Colégio. E tivemos alunos desse time, que foram para a seleção brasileira.

Entrevistadores: Tá, mas em qual modalidade?

Aristônio: Basquete.

Entrevistadores: Basquete?

Aristônio: Eu tive um time no Clube Municipal, time mirim, no qual dos 12 atletas, 10 eram alunos do colégio. Em 1979.

Entrevistadores: Os federados podem jogar na Olimpíada?

Aristônio: Podem jogar. Isso até em competições organizadas, tem. Hoje em dia não, mas anti- 
gamente o federado não podia participar, como se o federado fosse, culpado por ser um atleta melhor. Poxa! Tinha que dar parabéns! O atleta federado também passou pela base. Por que ele é federado não vai poder desenvolver o trabalho dele? Tanto é que hoje, nas Olimpíadas escolares, é indiferente se ele é federado ou não.

Entrevistadores: Vocês falaram aqui de habilidade, desenvolvimento de habilidades do aluno e falaram sobre a liderança dos alunos nas séries iniciais, que quando ficavam mais velhos, se tornavam chefes de bandeira. Então como se dá a preparação? Isso não se dá com o estudante somente com a competição, como é a preparação? Isso inclui os chefes de bandeira?

Miragaya: Vamos retornar à linha como o Raul vinha falando, quando ali no início se ouviu falar ou se pensou no porquê das quatro bandeiras.

Celby: O símbolo da UERJ foi o que motivou as primeiras bandeiras, as primeiras cores de bandeiras. Notem o seguinte: o vermelho, que sempre teve, é a chama da tocha que é vermelha e preta na UERJ. Então surgiu a bandeira preta. Azul são as letras que a UERJ tem em seu símbolo. E branca, é o seu fundo. Então essas foram as quatro primeiras bandeiras colocadas na história das Olimpíadas. E a ideia (nós viemos para cá, não para mudar, mas para mudar conceitos, trazer conceitos novos da Educação Física) se instalou junto com os professores que aqui estavam. A antiga $3^{a}$ série do Ensino Médio, o $3^{\circ}$ ano, não participava, porque tinha uma carga horária pesada na escola, que não permitia que ela formasse, treinasse e se organizasse. Mas, eles eram os organizadores. Eles eram os responsáveis. Com isso, o professor Aristônio, que também foi diretor dessa casa, talvez seja único que não perdeu comigo as edições das Olimpíadas e das bandeiras. Ele foi da primeira bandeira, pelo primeiro grupo, dirigente da bandeira de formação. Quando se perguntam como se formavam os profissionais e as pessoas, havia um diálogo muito amplo e aberto com os professores, com os pais. Essa ligação é um elo muito importante com os alunos, incluindo os professores e os funcionários fazendo parte dessa função. Então é uma casa em que se instala um triângulo equilátero, onde se tem uma formação profissional responsável por trabalhar os conhecimentos. Um grupo hábil de conhecimentos que sempre foi o dos alunos do CAp. Diferente de qualquer lugar, os alunos do Colégio de Aplicação sempre buscaram esse conhecimento e a família, que trabalhava junto com esses dois elos. Então era só colocar um ponto e girar esse triângulo equilátero para se tornar uma esfera. Foi uma junção de conhecimento, onde todos participaram. E aí se dá a oportunidade, não de quem tenha habilidade motora ou uma competência atlética, mas muito mais que isso. Quando o Raul 
traz para cá a questão da estafeta, que é uma das habilidades desenvolvidas no esporte, ou seja, o passar por diferentes etapas de obstáculos, ele traz algo que era construído por um tempo. Porque o Colégio de Aplicação é a maior base que tiveram, pelo menos no tempo em que eu estive aqui, e eu acredito que continue. O Colégio de Aplicação foi a maior base de conhecimento dos alunos da formação de Educação Física da UERJ. O Instituto tinha aqui um celeiro do aprendizado de crescimento; sempre teve isso. Raul passou por isso, todos que passaram por aqui sabem disso. Mesmo os que vieram de fora, foram banhados por esse símbolo da UERJ que se traduz, hoje, no Instituto de Aplicação. Tem isso também: esse símbolo de conhecimento. A UERJ sempre foi e sempre será um dos maiores celeiros de conhecimento do Brasil. De discussão política, discussão em formação, de avanços. Então esse símbolo foi o símbolo da I Olimpíada.

Entrevistadores: Como é que surgiu a bandeira amarela e deixa de existir a bandeira preta? Alguém tem essa explicação?

Raul, Ivan: Ele (Celby) sabe!

Celby: Entendida uma questão de identidade, transforma-se a bandeira preta em amarela, e introduz-se a bandeira verde, no lugar da vermelha. Mas, em algumas épocas, a bandeira vermelha continuou, continua a bandeira vermelha, a preta sai de vez.

Denise: A branca também.

Celby: A branca sai porque a camisa da escola é branca, identificava como uniforme da própria escola. Aí entra a bandeira verde, a azul continua e fica a vermelha.

Entrevistadores: Interessante isso, porque demonstra uma dinâmica da própria Olimpíada. Ela se repensa. Nem todos os processos da escola se repensam, né?

Raul: E ela se modifica Lincoln. E eu acho também que os grandes referenciais, todo esse CAp fica colorido. Eu acredito que o grande sucesso nesse quesito também se deve às Direções que sempre nos deram todo o apoio, e também à nossa união como professores. Nós fomos muito unidos. Brigas, por vezes, mas as nossas relações ultrapassavam o muro do CAp. Frequentava as casas, aniversários, churrascos, e você sabe muito bem como. Você, como diretor, entende a pressão que vocês sofrem dos pais, principalmente os que estão chegando aqui na escola, ao não conseguirem entender a Olimpíada como projeto pedagógico. Quando esses pais cobram de vocês ainda mais com greve, de dois em dois anos. Taí o Esequiel, como pai e professor que nunca cobrou. 
Todos: Risos de todos.

Entrevistadores: Porque ele também fez greve!

Todos: Risos de todos.

Raul: Porém, vocês sabem como eles cobram de vocês esta semana de aula, porque "vão perder aula". Não conseguiram entender. Porém, eu acho que o trabalho da equipe de Educação Física e o trabalho da Direção fizeram os pais aceitarem, terem essa credibilidade.

Entrevistadores: Gostaria de retomar Raul e os demais de vocês, sobre a preparação. Como vocês podem descrever a preparação da Olimpíada ao longo do ano? Isso é: como o projeto se integra aos objetivos pedagógicos das disciplinas nas diferentes séries?

Aristônio: Isso eu já falei mais ou menos. Olha só: a primeira fase é a da preparação da Olimpíada, onde se dão as inscrições para chefes de bandeira, depois a seleção dos candidatos a chefe de bandeira, depois a campanha dos possíveis chefes de bandeira.

Entrevistadores: Que anima o colégio todo. (risos)

Raul: Olha o $1^{\circ}$ segmento. Nós não temos a Olimpíada como culminância do nosso processo pedagógico não. Não é a culminância. Ela é uma etapa importantíssima! A gente não trabalha em função dessa Olimpíada, das competições em si. Nosso trabalho, nosso objetivo é a Educação Física escolar, toda essa parte de atividades e habilidades e isso veio a fortalecer a preparação das crianças. A partir de agosto. Antes de agosto nós não trabalhamos Olimpíada. Porém, no mês de agosto se inicia esse trabalho. Onde tudo é anotado. A participação da criança, ela sabe. Né, Denise? Tudo que ela aprendeu.

Denise: E uma coisa, também muito boa, que a Instituição conseguiu, foi manter o número de aulas de Educação Física.

Raul: Brigamos por isso também.

Denise: É que foi determinado que seria uma ou duas aulas por semana. E nós conseguimos, através de documentos, permanecer com as três aulas. Isso fortalece muito a Educação Física.

Celby: $\mathrm{E}$ isso é um grande diferencial.

Denise: Fortalecia-nos muito. Porque todo trabalho, todo material que a gente ia produzindo era junto com o aluno. Essas anotações que nos "enlouqueciam" com papeizinhos (o que hoje em dia se faz com laptop). A gente enlouquecia com as folhas e eles acompanhavam. E isso facilitava tanto a melhoria no desempenho, quanto à compreensão do que o Raul falou ainda a pouco, a compreensão do "eu vou participar com isso", "meu amigo vai participar nisso e naquilo". Por 
questão de conquista, né? Foi sendo conquistado. E havia espaço para todos, também para a compreensão. O "ah, eu sou muito bom, eu quero participar em todos". "Nós vamos fazer com que todos os amigos participem". E eles trabalhavam isso junto conosco. Essa formação, vista no que está certo, no que não está certo, e tinham um "grande medo" do resultado.

Raul: Por exemplo, o choro olímpico.

Denise: O choro olímpico (rindo), porque realmente evocava participação.

Raul: O "eu quero participar de tudo".

Todos: Risos de todos.

Denise: Mas isso faz parte da construção do cidadão, da coisa do respeito ao próximo, que valoriza demais a formação do aluno.

Raul: Tem uma coisa que eu lembrei sobre a turma do seu filho, Esequiel. Eles desenhavam a proposta de cada aula. O objetivo era que você tinha que quebrar o record. Mas o seu record. Você tinha que tentar quebrar o seu record, não o do colega. Então eles desenhavam, com o material disponível, colchões, bottons. E eles desenhavam, cada um fazia a sua estafeta. Se algum deles tinha dificuldade de fazer algum ponto, eles trocavam ou refaziam. Escolhíamos algumas estações e anotações e fazíamos uma votação para formar a estafeta.

Entrevistadores: Isso foi algo novo, surgiu espontaneamente, naquele grupo.

Raul: Em educação a gente faz tudo com amor. Eu acho que a gente aprendeu muito mais com eles, né, Denise? Aí eu me emociono. Eu vi na salinha, que hoje tem ar condicionado, graças a Deus, aquele negócio de plástico que eles fizeram na parede.

Denise: As crianças é que davam as ideias.

Raul: Aí havia inauguração. Vamos inaugurar hoje a estafeta de 2006!

Entrevistadores: Fala Ivan!

Ivan: Eu quero dar dois recados. O professor aqui, Celby, ele sabe, eu gostava também dos times dos jogos estudantis e do cafunfinha.

Miragaya: Dos nossos times, participação em campeonatos.

Ivan: Esta aqui. (mostrando uma medalha)

Denise: (Com a medalha na mão) Está escrito aqui "troféu Ivan Bigode". (risos)

Ivan: É isso aqui. (apontando para si)

Denise: Os troféus, as participações no Intercolegial, os campeonatos com outras escolas eram a demonstração de como foi plantado o interesse pelo esporte, pela atividade física. 


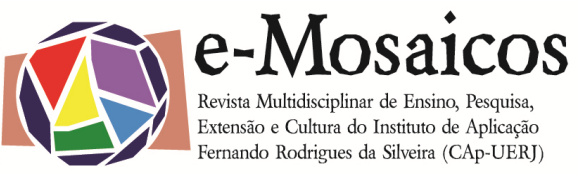

Raul: Nos finais de semana tínhamos que ir para os jogos, né?

Denise: Com a responsabilidade de estar junto.

Miragaya: O incentivo da participação tanto interna, como externa. O Ivan cuidava do jogo de cafunfa.

Ivan: Professor, você também já viu ganharem cinco times.

Denise: Cinco modalidades diferentes.

Miragaya: A gente viajava.

Entrevistadores: Eu queria saber um pouco mais como se dá a escolha dos chefes de bandeiras.

Aristônio: Como te disse, é legal porque parece uma eleição para deputados estaduais. Chega às vésperas, a gente tira toda propaganda, não pode ter boca de urna durante a votação e, com os vencedores decididos, começa a primeira reunião com os chefes de bandeira. A gente passa o que é Olimpíada para aqueles que querem. O que são os chefes de bandeira? O que é e qual vai ser a participação deles. A gente passa isso tudo. A gente está sempre do lado deles! A gente está presente nos treinamentos de bandeira para dar orientação. Por isso não ficam sozinhos. A gente está aqui, o professor sempre está. Dois ou três professores que acompanham os treinos de bandeira, aqui ou no Célio de Barros, com o treinamento de atletismo, durante o período todo. Aí chega outra fase de inscrição para selecionar os alunos, os atletas de cada modalidade. Do ano passado para cá nós mudamos, para não acontecer a perda de ponto por não comparecimento. Era uma tristeza, pois os chefes de bandeira se organizavam, montavam as equipes e, algumas vezes, na hora, os alunos não íam. Então, de dois anos pra cá nós estamos fazendo o seguinte: Eles têm uma relação. Nós temos uma relação de nomes e a que bandeira eles pertencem e nós vamos colocando, na hora do jogo, quem está participando. Se bater mais de duas coletivas, a gente sabe por que ele está anotado, e que ele já está participando. Então ele monta o time. Quando só tem cinco, se tiver que ter seis, ele chama um aluno que não está inscrito em nada. "Ó, você vai jogar aqui". Aí a gente passa, ou não. Não tem mais ocorrido perda de pontos por não comparecimento.

Miragaya: Na minha época de aluno, os chefes de bandeiras eram alunos do $1^{0}$ ano do segundo grau. Normalmente, dois de cada ano, normalmente dois meninos e duas meninas. Os alunos que passavam do $2^{\circ}$ ano para o $3^{\circ}$ ano deixavam de ser chefes de bandeira, e os que passavam do $1^{\circ}$ para o $2^{\circ}$ ano, continuavam e, teoricamente, esses quatro escolhiam mais dois. Quando você subia da $8^{\mathrm{a}}$ série para o $1^{\circ}$ ano, já existia essa expectativa de você ser chamado, ser esco- 
Ihido para ser chefe de bandeira. O que não foi, exatamente, o que aconteceu no inicio, né? o meu ano de chefe, 1985, me lembro por conta disso: foi o ultimo ano em que a escolha foi desse jeito. O professor, se não me engano, Mascarello, entrou no processo de Educação Física desse ano. A equipe toda apresentou a proposta para a gente, que a partir do ano seguinte, 1986, haveria uma eleição para chefe de bandeira. Eu acho que é aquela retomada de democracia, do direito de votar, escolher o presidente.

Raul: Saímos da ditadura, as "diretas já".

Ivan: Antigamente, era o chamado "tudo amigo nosso", "agora você... você", é "só falar, só falar".

Miragaya: Era só chamar, que o outro virava chefe. Normalmente não era uma escolha, não só por alguma amizade, mas por alguma liderança, ou porque o cara era um bom atleta em alguma modalidade.

Entrevistadores: Mas não era aberto a todos.

Miragaya: Aberto era, mas quem conhecia levava vantagem.

Raul: Havia algumas regras.

Raul: Aí a eleição é na aula de Educação Física.

Entrevistadores: Mas agora, em 2013, nós tivemos uma semana na qual a escola toda viveu em torno das candidaturas, das campanhas.

Miragaya: Na eleição existe um processo todo, que a gente depois, como aluno, tem que vivenciar e participar. Então essa questão pedagógica é muito importante. 0 aluno tem o período para lançar a candidatura dele, quer dizer, para inscrever a candidatura dele, depois aquela candidatura é avaliada em cima de conceitos e critérios: o fato de ser repetente, educação, comportamento, coisas que eles sabem, eles estão cientes de tudo desde o inicio, eles não são pegos de surpresa em nenhum momento. Então, enfim, eles lançam a candidatura, ela é aprovada, os pais assinam, porque eles são menores. Existe um período de campanha, então eles fazem campanha tipo "ficha limpa". Eles obviamente se autoavaliam. A campanha não pode ser burlada, nem ter trocas escusas. Tem que ser uma campanha pelas ideias dos chefes de bandeira. E, ao final dessa semana, desse período de campanha, existe o dia da eleição, que é o que eles estão vivenciando agora.

Ivan: O aluno aqui agora..., ele usa agora..., ele está colocando agora... (teclando)

Denise: Lançando a campanha dele no computador. 
Ivan: Isso, isso.

Entrevistadores: Pelo Facebook.

Entrevistadores: Lançando a campanha dele através do Facebook, houve uma expansão do processo.

Entrevistadores: Pelas redes sociais.

Miragaya: Como a outra questão que foi discutida rapidamente pelo Facebook: o aluno e o pedagogo postaram duas fotos da eleição, da campanha, a escola colorida, tudo pintado, adesivos, cartaz e aí a professora Sônia Wanderley fez um comentário: "Mas e esse lixo todo?" "Nesse lixo" também existe uma conscientização, para que, ao final da campanha, seja recolhido e jogado fora ou guardado, mas enfim, não pode ter lixo.

Entrevistadores: Eu tive a oportunidade de ouvir os alunos falando e agindo para evitar punição aos candidatos. Eles falaram comigo exatamente da necessidade dos candidatos de limpar.

Raul: A eleição limpa!

Miragaya: Não é uma simples escolha de chefe de bandeira. Existe um processo grande em cima disso. E aí, talvez, dando continuidade ao que você tinha me perguntado, após essa escolha, e também corroborando um pouco o que o Raul falou, de que a eleição não é o objetivo final do nosso trabalho, os alunos, os chefes de bandeiras escolhidos trabalham com os outros alunos para a formação de equipes, ao longo do ano. Horário de treinos de bandeiras aos sábados, horários de almoço, durante a semana. E nós damos aquela assessoria e a pincelada, no final do trabalho, em agosto e setembro.

Entrevistadores: Então tem um processo aí.

Raul: Ela faz parte de todo esse planejamento da Educação Física.

Celby: Um dado muito importante: Na I Olimpíada nós tivemos um aluno, Fontinelli, Carlos, ou melhor, Claudio Fontinelli, que por ter vencido a Olimpíada do Colégio de Aplicação, criou uma situação legal dentro do esporte competitivo brasileiro. O Carlos foi o primeiro atleta, sem estar vinculado a qualquer associação esportiva, a participar do Sul-Americano de salto em altura lá na Urca. Ele ganhou, foi terceiro colocado no Sul-Americano. Ele era do basquetebol, aluno daqui, juntamente com os três irmãos e nós conseguimos incluir o Claudio na federação e na confederação de atletismo, para participar dos jogos Sul-Americanos. Era visto como um paradigma estar afiliado. Para representar o Estado, o Município, não há necessidade de filiação. A filiação pode ser a posteriori. O mais importante é você ser capaz. E a Olimpíada sempre teve essa idei- 
a, de capacidade de todos. Ninguém fica excluído. Então é um fator muito importante para as pessoas saberem que, sendo do Colégio de Aplicação e participando do Instituto, ele nunca estará excluído. Então isso acontece porque há a questão da inclusão aqui, todos são participativos. Não me interessa qual é a minha função, se eu sou diretor ou se eu sou o professor de Educação Física. Eu estou participando do processo de educação.

Entrevistadores: Quais as dificuldades enfrentadas, ao longo desses anos, para realizar a Olimpíada? Vocês querem falar um pouco sobre isso? Por exemplo: da participação, da integração dos professores... Como vocês veem? Vocês sentem alguma diferença entre essa integração do colégio e a integração dos alunos das primeiras fases da Olimpíada e aquelas que temos agora? Aristônio: Completamente.

Todos: Risos.

Aristônio: Os professores de outras disciplinas... Já foi muito mais intenso... Hoje em dia está bem esvaziado em relação às outras disciplinas...

Entrevistadores: $\mathrm{E}$ você acha que isso tem alguma coisa a ver com a própria identidade em relação ao colégio? Você acha que isso é um sintoma de alguma coisa? Como é que você analisa essa situação?

Aristônio: Eu sou muito saudosista, porque sou da época em que o professor da UERJ não ganhava tão bem quanto os professores de outras instituições e ficava aqui. E acabava a aula e continuava na escola, conversando com o aluno, com a equipe. Hoje acabou e a maioria vai embora. Tem que ir para outro lugar, "não posso ficar aqui". Então essa relação está bem modificada em relação à nossa época, não é? Na nossa época já tinha o amor pelo colégio. E hoje é o "amor profissional". Nosso amor era diferente.

Celby: A primeira colocação, para dizer como funciona a atividade, mostra que a Feira de Ciência tinha um peso diferente do da Educação Física. Mas alguém com um olhar muito importante, o professor Miragaya, viu que dentro da Feira de Ciência, sem perder a Feira de Ciência, ele podia me dar três dias. Dentro da Feira de Ciência, que era a semana toda, para fazer a Olimpíada. Devemos inclusive buscar a Feira de Ciência.

Entrevistadores: Uma observação é que acabou a Feira de Ciência e o CAp tem uma semana de Olimpíada (risos de todos). E outras dificuldades? Você queria falar alguma coisa a mais sobre isso?

Celby: Este resgate é inclusive uma contribuição ao que o professor Miragaya deu para a Educa- 
ção Física, quando, abrindo mão na Feira de Ciência, ele permite a introdução da Olimpíada. Então, na continuidade da Feira de Ciência, hoje, tem uma semana. Que a Educação Física busque outra vez a semana da Feira de Ciência.

Entrevistadores: Agora Denise, que dificuldade você enfrentou?

Denise: A dificuldade que a gente enfrentou é que a gente tinha que se preparar para organizar, para pedir o espaço. Quando a gente começou a usar o Célio de Barros, a gente tinha que se organizar porque havia toda uma disputa entre todas as atividades que aconteciam ali. Então a gente precisava pedir com antecedência, fazer aquelas solicitações. Às vezes tínhamos dificuldades em relação ao cumprimento do que os organizadores dos espaços exigiam, contando com a Associação de Pais para suprir as deficiências de pagamentos.

Entrevistadores: Como você disse, nem o CAp nem a UERJ conseguem ter espaço e infraestrutura para dar conta do evento. Onde ele já ocorreu?

Aristônio: Nós já utilizamos vários espaços. Quando nós tínhamos natação, nós utilizamos o Júlio D'Lamare, o Parque Aquático da SUDERJ, o Clube Municipal, o Colégio Militar, o Grajaú Country Club, o Tijuca Tênis Clube. A gente sempre tem uma parceria com o Colégio Militar para o treinamento de atletismo. De alguns anos para cá, nós estamos treinando no próprio Complexo Célio de Barros. Lamentavelmente, o governo vai derrubar, para se tornar um estacionamento. Isso é terrível, um espaço único.

Entrevistadores: Vem de onde? Vai para... Não vai para lugar nenhum?

Aristônio: Dizem que vão construir, dentro da Quinta da Boa Vista, um complexo esportivo, com pista de atletismo, parque aquático. Vamos aguardar. Quem viver, vai ver... (risos)

Entrevistadores: E quando chovia?

Raul: Na VIII Olimpíada eu havia preparado e havia conseguido um ônibus para levar as crianças. Da Haddock Lobo até o Célio de Barros e lá íamos desfilar e escrever VIII Olimpíada. Ensaiamos, conseguimos mobilizar o colégio, todo mundo ajudando, foi e fizemos. No sábado de manhã, antes de tudo, era uma chuva, aí o Paulo Fonseca conseguiu o Maracanãzinho. E aí era: "Gente, tem que fazer! Tem que fazer, mas como?". Eu tinha ensaiado no Célio de Barros. Mas Deus é grande, e com muita ajuda, isso que é fundamental, ajuda dos colegas, da equipe, das professoras do primeiro segmento, da Leila, dona Zulmira, dona Ione, que ajuda! Muita ajuda! A dona Zulmira ajudou muito. Aí conseguiram escrever VIII Olimpíada, não é Ivan? No outono, os pais queriam baliza e eu era pedagogicamente contra treinar a baliza, mas já que queriam. 
Todos: Risos.

Raul: Tivemos muitas dificuldades. Nós temos uma semana de folga depois das Olimpíadas, porém todos nós fazemos os horários e damos um dia a mais, concorda? Todos nós, tínhamos isso e uma direção quis tirar esta semana. Mas não me pergunte quem foi não.

Entrevistadores: Fui eu? (Lincoln, aos risos)

Todos: Risos e gargalhadas.

Raul: Não, não foi você. Mas não vou dizer não! (risos)

Todos: Risos e gargalhadas.

Raul: Mas nós tivemos mais apoios que valeram, então não era dificuldade não.

Celby: Havia também uma incompreensão da Universidade. Havia um distanciamento da Universidade. A Universidade não olhava, apesar de usar o Colégio de Aplicação, efetivamente, a Educação Física. Mas a universidade como um todo não olhava com bons olhos o Colégio de Aplicação. Então isso também criava dificuldade de uso das instalações. Várias vezes nós viemos buscar outros lugares por não termos a Universidade à nossa disposição. Buscava-se o Colégio Militar, o Bradesco, o Instituto de Educação, a Escola de Educação Física do Exército.

Ivan: Vale lembrar que no CAp antigo, na escola, o lugar que antigamente era nosso. Mas, às vezes, havia do lado aqui alguns tiroteios, e ai a gente só escutava o "pow-pow-pow". Era assim o morro do Turano! Depois no Maracanã. E aí eu gritava: "Vamos embora, vamos embora!".

Todos: Risos de todos.

Entrevistadores: Sim. E houve uma dificuldade em uma determinada Olimpíada na qual houve um tiroteio externo. É isso?

Entrevistadores: Foi quando a escola se mudou.

Entrevistadores: Aí perdeu o espaço. É isso? O espaço que a Educação Física tinha. Por conta da mudança se perde.

Ivan: Aí... acabou. Fomos para lugares diferentes. Precisávamos voltar, voltar para um lugar nosso.

Entrevistadores: Enquanto isso: foram fazer no Maracanã.

Ivan: Todo mundo estava junto: "Vamos lá, vamos lá!" Havia os dias do "pow, pow"! Eu falava: "Espera aí um pouquinho".

Miragaya: Os meninos da comunidade pulavam o muro para jogar bola.

Ivan: Também. 
Entrevistadores: Quando perguntados sobre como se sentiam no Campus Maracanã, os meninos diziam: "Aqui é maravilhoso, eu me sinto em um shopping-center, aqui tem de tudo!".

Todos: Risos.

Denise: Mas isso também acabou contribuindo para a formação dos estudantes, até isso dava para ser trabalhado. Pois havia a preocupação com a formação do aluno, mostrando que não era a condição ideal para o trabalho. Até isso problematizamos e orientamos.

Celby: Tenho outra da sua época (aponta para Ivan). A abertura ao pessoal do Turano para jogar sábado lá no Colégio de Aplicação mudou completamente a relação do grupo, do tipo entre a comunidade e a escola. Na época nós conseguimos colocar na estrutura da escola, que nos sábados de tarde eles podiam jogar no CAp. Então passou a liberar o sábado à tarde, para a comunidade usar a quadra, entendeu? Foi muito legal.

Ivan: Agora eu lembrei de um sufoco, no Turano. Antigamente, na época em que a nossa escola estava lá, houve uma tarde em que aconteceu uma perseguição e a morte do filho de um funcionário que trabalhava na escola. Aí eu parei tudo. Eu, sozinho! Eu, sozinho, orientando aos demais para não correr.

Miragaya: Esse rapaz estava fugindo, entrou na cabinezinha que ficava na portaria e o bandido foi atrás e causou tudo isso.

Entrevistadores: Nós temos no Instituto, na Universidade, três pilares fundamentais, três vertentes de atuação na Universidade. Que são a pesquisa, o ensino e a extensão. De que modo vocês acham, acreditam que essas atividades, a experiência da Olimpíada, ao longo desses 40 anos, influenciaram ou influenciam iniciativas similares nas escolas, públicas ou privadas?

Celby: É um referencial. Eu hoje ainda continuo trabalhando na escola privada. Conhecimento não se perde porque você fica mais velho. Nunca! E essa troca, essa modificação que incorpora, faz com que, agora, a relação com meu aluno esteja valendo muito. Nos seus caminhos anteriores, só não posso voltar, mas posso dar passos novos. Passos muito mais profícuos. Nós tivemos sempre como referência a Olimpíada e as diversas mutações. Do Colégio de Aplicação saiu o trabalho para Parintins, que deu os resultados que deu. De um trabalho no Colégio de Aplicação, onde eu trabalhei num processo idêntico à Olimpíada do Instituto. Lá nós temos hoje, em Campos, um trabalho no Tamarindo, uma comunidade similar à do Turano. Então eu acho que os três níveis ficam presentes com esses tipos de processos. A minha visão é que todos os três níveis permitem isso. Mais ainda, estimulam a pesquisa. Onde estão os primeiros? Onde estão 
os que passaram pela Olimpíada? Onde estão os ex-alunos, profissionais da educação, do CAp, como a professora falou, que gostaram e definiram sua profissão? Eu entendo que faz uma diferença muito grande essa experiência do Colégio de Aplicação em termos da formação, da continuação e, principalmente, em termos da pesquisa.

Raul: Nós éramos a terceira escola no Brasil a ter a Olimpíada no sentido diferente. É o espaço de pesquisa, quando a gente fala dessa trança que o CAp fica colorido. Várias escolas hoje, do Rio de Janeiro, usam o parâmetros das bandeiras. Na verdade, há várias escolas que usam nosso modelo. Lógico que modificando, de acordo com as suas características. Este é um espaço do ensino e da pesquisa.

Miragaya: Eu já comentei com os colegas daqui, em 2011, se não me engano. Eu acho um absurdo a gente não ter nenhuma produção cientifica baseada na Educação Física. O número de dados, desde participações, a modalidade mais praticada, a relação interpessoal. Como o Raul falou, há poucas escolas no Rio de Janeiro que têm Olimpíadas como a nossa. A maioria das Olimpíadas é turma contra turma. Eles não chamam nem de Olimpíada, chamam de jogos internos. Joga uma turma contra outra turma. Aqui, através desse projeto, há um envolvimento entre a escola inteira! Desde o $1^{\circ}$ ano até o $3^{\circ}$ ano do Ensino Médio. A escola inteira é organizada e sorteada em quatro bandeiras. Então você tem relações em que estudantes são de dois ou três anos diferentes, mas são amigos, saem da escola, são relações ruins também, mas também as relações amorosas, afetivas com namoros que aparecem na Olimpíada. As emoções olímpicas. Ao final, tem o choro Olímpico. Então o que tem de dados de movimento desses três pilares, que podem dar até em outra pesquisa: quantas Olimpíadas surgiram através do modelo da Olimpíada do Colégio de Aplicação?

Raul: No próprio InterCAp (projeto de formação continuada para professores das redes públicas do interior do estado do Rio de Janeiro), os professores Francisco e Marinho, nas suas ações, citam a Olimpíada. Eles passam o modelo da nossa Olimpíada.

Ivan: Há pessoas que casaram, eram alunos e viraram professores como Fabinho Eiras e Luciana, Gil e Claudio Abuassi. Chefes de bandeira.

Todos: Risos de todos.

Entrevistadores: Nesse espaço que a gente tem hoje - que hoje você vivencia como visitante, Aristônio, mas antes como professor - nessas questões das mudanças, das adaptações e até das dificuldades - e vocês viveram as duas realidades, o sair do Turano, vir para cá - no que 
isso facilitou ou dificultou a organização do processo da Olimpíada? E vocês não sentiram na Educação Física? Isso eu lembro, como professora, a Educação Física perdeu muito de infraestrutura com uma salinha.

Aristônio: Sim.

Entrevistadores: Quando você, Aristônio, estava na direção, você tentou arrumar um pouco a infraestrutura. Como é que você fez? Como foi isso?

Aristônio: Na gestão, na obra de cobertura do ginásio, isso foi uma loucura. Me prometeram entregar a cobertura em três meses e levou um ano. A gente não podia usar espaço nenhum, nenhum ideal para a aula de Educação Física, porque a gente não tinha. As aulas foram todas feitas dentro de salas de aula comuns.

Entrevistadores: Foi quando mesmo a sua gestão?

Aristônio: Foi de 2000 ao início de 2004.

Entrevistadores: Foi nesse período que essa cobertura da quadra foi feita?

Aristônio: Durante um ano, nós ficamos, acho que de 2000.

Entrevistadores: Como a Educação Física se resumia?

Aristônio: A gente trabalhava dentro da sala de aula. Todo o trabalho foi feito em sala de aula.

Entrevistadores: E mesmo assim, teve a Olimpíada?

Aristônio: Sim, teve a Olimpíada.

Aristônio: E é a época em que nós fomos para a UERJ também. Nós passamos um período na UERJ. Para a Educação Física foi bom. Nós utilizamos toda a estrutura da Faculdade de Educação Física. Nós utilizamos campo, quadra, ginásio... tudo. A gente atrapalhou um pouquinho a estrutura de lá da Faculdade de Educação Física. A gente usava o mesmo espaço.

Entrevistadores: Eles reclamaram por pouco espaço também, mas a gente estava lá.

Raul: Posso falar? Olha só, foi horrível, né Lincoln? Caiu, nós tínhamos uma menina Rejane, que ela tinha um record de salto em distância. Na Haddock Lobo, nós tínhamos caixa de areia, as crianças saltavam, eles faziam a medida. Aqui, foi horrível. Eu me sentia inseguro ao trabalhar o salto em distância para as crianças. Nós tínhamos que fazer o rodízio. No meu discernimento, se eu não brigasse, às vezes, nem ia para a quadra. Mas eu tinha que estar brigando! Vamos fazer rodízio, eu preciso treinar também, eu preciso das marcações! Não é, Denise?

Denise: É porque a gente precisou lutar para ter um espaço. Era uma luta por um espaço. E deu insegurança. E o medo da gente de colocar a criança para se lançar no local que não era o ide- 
al.

Miragaya: No Turano, o espaço externo também tinha uma caixa de areia e um espaço maior. Hoje a gente tem uma quadra menor do que era a quadra externa. Essa também demorou um tempo para ser coberta. E aquele espaço aqui, que vivem prometendo, que a UERJ vive prometendo, a obra do chamado "chinês" que não sai.

Raul: Culturalmente, infelizmente a Educação Física nas escolas sempre atuou nos espaços marginais. Pela minha experiência de município e tal, quando a gente estava na Haddock Lobo, não era essa a realidade. Lá nós não atuávamos em espaços marginais. Nós tínhamos uma sala imensa lá em cima, duas quadras, lá embaixo tinha um pátio em que eu adorava dar aula e areia. Viemos para cá e fomos trabalhar nos espaços marginais mesmo!

Entrevistadores: Mas isso é que está no conjunto dificuldade. Não dava pra cruzar os braços.

Raul: Grandes dificuldades. A criança perdeu! Mas nós tínhamos aquela máxima: "A gente tem que ser feliz aqui". Não adianta ficar reclamando. Mas agora a criança perdeu.

Entrevistadores: Trata-se das dificuldades enfrentadas para realização de um evento, né? Um evento com essa envergadura tremenda.

Aristônio: É! A dificuldade que a gente teve e que tem ainda é em função de financeiro. Nós ficamos aguardando até o ultimo dia, até não poder mais, para sair o SIDES especial da Olimpíada, né? Na Universidade tem que ser liberada uma verba para que a gente possa comprar medalhas, o material que vai ser utilizado, o aluguel do Célio de Barros. Esse ano que passou, só isso custou quatro mil e poucos reais, tá? Mesmo sendo um órgão público como a SUDERJ e o CAp uma escola pública. Até um órgão público também tem que pagar. Porque existe um quadro móvel, uma pessoa que vai limpar. Porque não é dia de trabalho da pessoa. Um porteiro, um segurança. São pessoas que trabalham dentro do atletismo. Montar a caixa de salto, montar a caixa de salto em altura.

Celby: No Colégio de Aplicação do Estado, deveria haver um olhar mais diferenciado. Distribuindo, disponibilizando estruturas prontas, organizadas que poderiam ser maximizadas pelo mundo. Um fator importante: o Colégio de Aplicação da UERJ, diferentemente de todo o Estado do Rio de Janeiro e de alguns estados do Brasil, tem três aulas de Educação Física, no seu currículo. Isso é um grande ganho e um ganho que nós temos que manter, porque talvez sejamos muito poucos. O município do Rio de Janeiro está trocando, não está dando mais aula. Qualquer um dá aula de Educação Física, o que não é por aí. Então eu acho que é um ganho. Mas é pre- 
ciso haver, também por parte das direções, sejam as do Colégio, sejam as da UERJ e do Estado, uma obrigatoriedade de olhar pelo colégio. O colégio tinha que ter resultado, não pela Educação Física, pelos seus resultados, mas o resultado de cidadania. Então colocar no mercado profissionais de mais alto nível, colocando em todos os níveis em todos os cursos. Educação Física é um deles, mas em todos os cursos, colocando como cidadão, que começa aqui no primeiro segmento, no $1^{\circ}$ ano. É preciso haver uma responsabilidade. Isso aí é uma briga que eu acho que todos nós devemos fazer. Não cabe você sair de um lugar que tem potencial da atividade ser maximizada, colocar num local onde ela é subtrabalhada. Nossos governos, do Estado e da Universidade têm que olhar de maneira diferente para esse campo. Principalmente, ele sendo o Colégio de Aplicação, onde todas as práticas pedagógicas se constroem para um mundo melhor, quiçá o mais rápido possível.

Entrevistadores: No caso, sempre teve essa semana em que não há aula das outras disciplinas para ter Olimpíada?

Aristônio: Sempre foi assim... Sempre foi assim!

Entrevistadores: Então é sempre assim. Ou seja, sempre teve essa Olimpíada como atividade importante no projeto pedagógico.

Aristônio: Como tinha também uma atividade importantíssima, que acabou também, e você era do colégio, você pegou o finalzinho disso, que era a Semana Comunitária. A gente deixou de têla. E era uma coisa pedagogicamente importante. A vivência do aluno se ampliava e, quando a gente estava no Turano, era importante. Os alunos do que hoje é o Ensino Médio subiam morro para fazer pesquisa, levantamentos socioeconômicos. $E$, naquela época, o Colégio era divido também: o Clássico, Administração, o Biomédico e o Tecnológico.

Entrevistadores: É. A gente ficaria aqui muito tempo contando a história, a gente aprendeu muito. Eu estou aqui ouvindo vocês, estou pensando no potencial que a gente tem de trabalho de pesquisa, de extensão e de transferência dessa bagagem, deste conhecimento apurado, dos processos que vocês aqui descreveram, para outras frentes e outros espaços. Essa entrevista vai ser transcrita e publicada na revista. Haverá um audiovisual com os vídeos, que são extremamente ricos. Não sei se há mais alguma pergunta, mas eu (Esequiel) quero, de antemão, agradecer a presença de vocês, a vinda de vocês, os ensinamentos, a oportunidade de aprender com vocês, imaginar vocês atuando dentro e fora do CAp. Celby, que eu não conhecia, mas fiquei feliz em ter conhecido. O Miragaya eu já conhecia daqui. A gente, às vezes, mantém con- 
tato, mas é... gostei muito. Matei a saudade de pessoas queridas ao longo do tempo. Mas eu gostaria de ouvir uma fala de vocês... Seria interessante se vocês fizessem uma fala final. Querem acrescentar alguma fala de vocês, sobre experiência de vida no CAp, nesse registro que a gente está produzindo com o vídeo?

Ivan: Então lá vai, eu achei muito legal!

Todos: Risos de todos.

Ivan: Obrigado!

Entrevistadores: Posso agregar uma coisa na questão dele? Se viessem algumas palavrinhas na cabeça de vocês, sobre o que é a questão das Olimpíadas, o que vocês diriam? Aí pode ser a resposta que vocês vão dar para ele.

Denise: O grande valor é a integração. Integrar toda a Instituição. Por vezes, assim, a cada ano, existia uma grande oportunidade de todos os segmentos da escola, conhecerem um pouco mais um ou outro e de contribuírem para o crescimento do outro. Em todos os setores. Eu acho que a Olimpíada tem esse grande valor. Dentro da sociedade mesmo é a integração de todo mundo. E acho assim, para não ser perdido, apesar de ter 40 anos, ela é bem madura, bem firme, mas acho que para não ser perdida deveria ter mais estímulos para que continue acontecendo, em relação ao espaço, em relação à escola abraçar sempre, mas para que não se perca a oportunidade de fazer esse evento.

Raul: Antes de tudo, só um fato, só uma curiosidade que eu queria falar, pois acabei esquecendo de um fato. Apesar da professora Catarina não estar presente, ela foi nossa aluna, do $1^{0}$ segmento. Era um jogo de handebol, na Olimpíada, lá na rua Barão de Itapagipe, e mesmo com a presença da equipe de médicos e da enfermeira "Careca", a Catarina, se machucou. Entrei na quadra, chamei o médico, levamos Catarina para a sala do médico. Nisso, a mãe da Catarina, que estava lá na quadra, abriu a porta e quando viu a filha dela deitada disse: "Vamos embora Catarina, que o time está perdendo, vamos embora Catarina, levanta daí!" Isso foi sensacional! Todos: Risos de todos.

Entrevistadores: Virou professora de Educação Física.

Todos: Risos de todos.

Raul: Isso me marcou muito! E num outro episódio, havia um aluno de Denise. Veio a estafeta, a prova, e tinha uma corda. Eles tinham que passar por essa corda. A mãe, na hora em que a criança foi passar, meteu a mão na corda e levantou para a criança poder passar. Os pais quase 
bateram nela! Foi uma confusão, anula ou não anula? E depois essa mãe conversou com a gente, colocou diversas particularidades e situações, que nos fizeram chorar, né, Denise? Mas eu agradeci muito a Deus, muito, muito, por um dia, eu ter podido trabalhar no CAp. Como eu aprendi. Como eu aprendi com esses alunos do primeiro segmento. Eu tenho muito a agradecer às direções, à minha equipe de Educação Física, a nossa união. Porque isso é o reflexo das aulas de Educação Física, eu posso garantir. O CAp é um dos poucos colégios em que esses professores trabalham mesmo. Aqui não dá pra enrolar. Aqui se pega duro, pesado, é verdade. A Olimpíada é um reflexo da aula. Agradecer aos amigos, a vocês, à Denise, ao Celby, aos colegas, Miragaya. Obrigado. Obrigado mesmo.

Celby: Eu queria agradecer a Deus que me deu a oportunidade. Eu tive a oportunidade de acompanhar a trajetória toda da Olimpíada, vivenciar como ela se transforma pintada com novas cores, com alguns que eu vivi, como o Ivan, Mascarello. Denise, eu vi essa criança (passa os braços em Miragaya) na escola e hoje profissional. Raul foi companheiro de trabalho, de formação. Mas assim, Olimpíada, para mim, se traduz em 3 nomes: Tradição, Competência e Cidadania. Tradição enquanto ela mantém valores. E mesmo com novas pinturas, eles têm uma espinha dorsal forte. Competência de conseguir que todo grupo de professores, funcionários, direção, pais, alunos, enfim, juntos, construam e mantenham essa continuidade. E Cidadania, porque ela se transforma em uma pesquisa realizada, permitindo uma nova pesquisa. A Olimpíada do Colégio de Aplicação permite realmente aquilo que eu falei: na formação, na extensão e na pesquisa, um dado concreto de amor que pode dar certo, em qualquer terreno em que seja colocado. Desde que tenha tradição, competência e cidadania. Essa é minha visão de Olimpíada, que cresceu muito com este contato, que me permitiu te conhecer, Lincoln, e, além disso, queria lembrar dos nossos grandes baluartes, que nos permitiram fazer isso juntos: professor Paulo César, professor Miragaya, professor Moisés, professor Faria e tantos outros juntos, os meus companheiros, que na época me somaram. Eu falo companheiros, eu não falo somente dos companheiros da Educação Física. Eu falo dos companheiros na escola. É uma escola única. É um momento diferente. Poder dizer, Ivan, que eu fiquei muito feliz quando soube de você, quando soube da sua indicação pelo Edinho. Pois a Rosane e a Heloisa já eram da nossa equipe, já vinham do IEFD, já faziam parte de nossa equipe. E quando Edinho trouxe você, você e o Mascarello, me substituindo, deram passos novos. No atletismo se diz o seguinte: "você só cumpre a sua obrigação, quando você coloca o bastão na mão de quem continua competindo, 
de quem continua caminhando. Então a passagem do bastão só é correta, quando você realmente deixa o bastão e vê que aquele revezamento continuou." Eu fiquei muito feliz, quando fui deixar na mão do Ivan, ele recebeu esse bastão e foi passando para cada um, cada um, cada um e outro, e hoje ele conseguiu, sentado aqui, ver a construção. Porque a ideia você pode ter, mas quem constrói é quem continua. Parabéns, amigão! (apontando para Ivan) Parabéns mesmo!

Miragaya: Muito emocionado, eu vou dizer, se não, depois não vai dar para falar. Ele falou de tradição, de competência. É, para mim Olimpíada é emoção! Muita emoção. Principalmente, com os alunos. Aprendizado... muito. E paixão. Muita paixão. Tudo isso. Eu me lembro de algumas coisas... Eu passei o segundo segmento inteiro ouvindo os colegas mais novos: "Ah... O Tio Raul, porque o Tio Raul...". Poxa, quem é este cara? Esse cara não foi meu professor. Por que eu não tive...? Mas, foi com ele que eu aprendi horrores... Aprendi... Sei lá... Quanta bagagem eu aprendi... Colégio de Aplicação, Olimpíada... foi conhecimento, aprendizado... foi tudo. Queria agradecer muito, por esses tantos anos de CAp. Desde o dia em que eu entrei tenho orgulho. Até os outros dias em que eu entro e saio de novo. Como professor, como convidado, como colega e queria agradecer esse convite, que realmente... E quando o assessor ligou, eu até falei para ele: - Eu não sei o que o Lincoln está arrumando, mas eu vou. Ele perguntou se eu tinha o telefone do professor Celby. Eu falei: - Pode falar para o Lincoln que eu não sei o que ele está arrumando, mas eu vou, eu estou dentro. E na carta convite que ele fez, que era pra eu entregar na escola do município para poder vir aqui, às vésperas do dia dos namorados, ele disse que o CAp ficaria orgulhoso se eu pudesse vir aqui e falasse deste enlace que eu tenho com a Olimpíada. Foi isso o que me fez vir aqui. Tinha tudo a ver.

Miragaya: E realmente isso aqui é um casamento, como o Raul lembrou sobre o Ivan. Você perdeu o sábado e o domingo para jogo, foi válido. Em todas as escolas em que eu trabalho, na prefeitura, pela qual eu tenho um pouco mais de carinho, talvez pela carência deles, né? Eu faço igualzinho o Ivan e o Mascarello faziam. "Boto oito" no meu carro. Sei que é perigoso, mas vamos lá. Se "tem", vamos! Mas, eu aprendi aqui e faço assim. Perco o sábado, mas saio feliz dali. É uma alegria, porque eles realmente não têm. E eu faço questão de fazer. E essa escola em que eu estou atualmente, que é a Epitácio Pessoa, entrou com um projeto na prefeitura de horário integral, por isso eu não continuei no CAp, porque eu tive que me dedicar lá em horário integral. E justamente por acreditar, por ser filho de uma escola integral, tenho certeza que é 
isso que vai fazer diferença na vida deles. E eu ainda vou fazer uma Olimpíada lá (todos riram). E eu quero fazer tudinho direito. Com abertura, fogo simbólico e tudo que tem direito.

Entrevistadores: Eu queria agradecer a vocês, agradecer informalmente, porque eu não me represento. Eu represento essa tradição de mais de 55 anos. E Deus quis que eu estivesse aqui, com esse companheiro que propôs pegar esse barco aqui. $\mathrm{E}$ a gente resolveu completar o trabaIho da professora Sônia, que também teve uma contribuição importante nisso. Contando ainda com o trabalho das bolsistas para continuar a passagem do bastão. Sem essa passagem do bastão, nada disso funciona. É engraçado... a escola às vezes fala do "arquivo morto" e sei que vocês não são. Vocês são memória viva! E isso que vocês estão fazendo, que o Esequiel disse, vai ajudar a formação, eu não diria só formação profissional, mas eu diria principalmente de formação de caráter, de outros que virão. Na medida em que a gente conseguir disponibilizar esse material, passar um pouquinho de tudo que vocês falaram para alguém que milite na profissão ou estude aqui. Para alguém da Educação Básica, para esses meninos e meninas que vão ser chefes de bandeira, que um dia podem se espelhar nesses depoimentos aqui.

Miragaya: Eles não precisam ser professores, mas quando eles forem trabalhar, que sejam líderes mesmo. Eles serão democráticos, eles farão tudo o que aprenderam aqui.

Entrevistadores: Bom, apenas mais uma, aproveitando o tom saudosista, que é a integração da comunidade escolar com o evento. É claro que o saudosismo não vai desaparecer, mas como é que você gostaria que a Olimpíada se desse?

Aristônio: Eu gostaria que nesse final de Olimpíada os professores dos outros Departamentos se integrassem às bandeiras como era antigamente. Professor de Geografia ajudava os alunos na preparação, na organização. Participavam. Eles adotavam uma bandeira. E eles faziam parte integrante dessa bandeira. E hoje em dia, só professor que tem filho é que vai e que comparece aos nossos eventos.

Entrevistadores: Você queria falar mais alguma coisa sobre Olimpíada, sua participação na Educação Física, o que o projeto da Educação Física aponta para a escola?

Aristônio: Deixe-me falar só um detalhe aqui. O projeto Olimpíada Escolar, Olimpíada Interna do CAp faz parte, ele faz parte do projeto de extensão registrado na SR-3. Ele é feito em conjunto com a participação das equipes da escola em outras competições, através da Olimpíada. Nós montamos as equipes que representam nossa escola nas Olimpíadas escolares organizadas pela secretaria de estado de esporte, pelo intercolegial organizado pelo jornal O GLOBO e para ou- 
tros torneios nos quais o colégio é convidado participar como o do centenário de São Jose, e de outros. A equipe de Educação Física organiza a equipe do colégio que é convidada a fazer parte do projeto de extensão. Quem está responsável em 2012-2013 pela coordenação do projeto de extensão, é a professora Eliana. Eu estou na extensão, mas não sou o responsável direto, sou da equipe. E é um prolongamento, um prolongamento até o final da nossa Olimpíada. Aqueles alunos que se destacam nas modalidades que a gente possui são convocados para representar o colégio, fora da instituição.

Entrevistadores: É isso! Porque a Olimpíada não é um processo profissional. Ela é um processo de formação em todas as suas etapas. Então o que vocês disseram pra gente, foi isso. Eu fico muito feliz. O CAp reconhece a vocês. Porque vocês não foram egoístas, porque vocês fizeram a costura, lembrando os nomes de pessoas que já passaram e que ainda estão aí. Que vão continuar, devido à entrevista de vocês. Porque há entrevistas que a gente faz que são apenas "eu, eu, eu". E vocês foram o tempo todo muito generosos. Quem fez, como fez, onde agiu o coletivo, a equipe, e isso causa para a gente orgulho, apesar de todas as dificuldades que vocês enfrentam, enfrentaram e que ainda vão enfrentar com a gente, porque a gente coloca vocês também nisso. É demais o que vocês trouxeram para a gente hoje, foi uma aula de cidadania. Aula de ser professor, ser profissional e de ser parceiro. Então assim, agradecemos muito a vocês.

Entrevista concedida em 12 de junho de 2013, no CAp-UERJ. 